\title{
DETERMINATION OF SAFETY PROFILE OF REPARATIVE ACTIVITY OF THE NEW HYGIENIC PRODUCT “APIPROL"
}

DOI: 10.36740/WLek202108118

\author{
Lyudmila Kravchenko, Elena Appelkhans, Liana Unhurian, Sergey Shcherbakov, Olga Goncharenko, Yana Ivanova
}

ODESA NATIONAL MEDICAL UNIVERSITY, ODESA, UKRAINE

\begin{abstract}
The aim: To prove safety of the new elixir and determine the effect on regenerative processes under conditions of the experimental trauma.

Materials and methods: The formula of the new dental elixir "Apiprol" includes biologically active components of bee products (propolis, comb capping wax), plant origin compounds. The elixir was single administered, intragastrally to white nonlinear mice weighing $(22 \pm 2) \mathrm{g}$ at doses at $50 \mathrm{mg} / \mathrm{kg}, 500 \mathrm{mg} / \mathrm{kg}, 5000 \mathrm{mg} / \mathrm{kg}$. Acute toxicity of the new hygienic product "Apiprol" was investigated by a single application at the rate of $1000 \mathrm{and} 5000 \mathrm{mg} / \mathrm{kg}$ animal weight. Subacute (chronic) toxicity was studied when elixir was applied to the skin of 10 mice at a single daily dose of $500 \mathrm{mg} / \mathrm{kg}$ for one month. A local irritant effect of the elixir on the oral mucosa was examined in 14 white rats daily after application for 3-5 min. The study of reparative activity was carried out on an experimental model of the wound process.

Results: The elixir's components promote tissues regeneration, rapid epithelialization and wound surfaces healing, having a highly immune stimulating activity and antibacterial properties.

Conclusions: The performed study proved a complete safety of the new elixir "Apiprol" and indicated a necessity of the further development of this preparation in order to create a greater variety of dental means produced in Ukraine.
\end{abstract}

KEY WORDS: new elixir, white rats, oral mucosa

Wiad Lek. 2021;74(8):1885-1890

\section{INTRODUCTION}

Prevalence rate and difficulties of prevention and treatment of diseases of periodontal tissues, oral mucosa $(\mathrm{OM})$ with metabolic syndrome (MS), which differs by different trigger mechanisms of disorders (fat, carbohydrate metabolism, vascular endothelium, etc.), make them an important problem of dentistry $[1,2]$. The known methods of prevention and treatment do not always provide the proper therapeutic effect, so adequate treatment requires a reasonable use of agents that directly affect the injured areas in the oral cavity, removing stomatogenic risk factors, or correcting changes that have occurred against the background of the concomitant pathology.

Based on the analysis of available literature data, often contradictory, the development of a new oral hygienic drug "Apiprol" for improving the treatment and prevention of periodontal tissue diseases, OM against the background of MS is considered well-timed and economically justified.

In the course of implementation of the state financed research project of the Ministry of Health of Ukraine №0120U002197 "Development of new therapeutic and prophylactic agents and pathogenetic substantiation of their use with inflammatory periodontal diseases against the background of metabolic syndrome" on the basis of the Odesa National Medical University, the formula of a new hygienic preparation for oral cavity "Apiprol" on the basis of biologically active substances of bee products and natural compounds was developed, which requires detailed study [3].

\section{THE AIM}

The aim of the work is to investigate safety of the new product for oral cavite and determine the effect on regenerative processes under conditions of the experimental trauma.

\section{MATERIALS AND METHODS}

The study of acute toxicity of the new hygienic preparation in the form of elixir "Apiprol" was performed according to the methods [4].

The elixir was single administered, intragastrally to white nonlinear mice weighing $(22 \pm 2) \mathrm{g}$ at doses at $50 \mathrm{mg} / \mathrm{kg}, 500$ $\mathrm{mg} / \mathrm{kg}, 5000 \mathrm{mg} / \mathrm{kg}$. For intragastric administration of the elixir, the animals were provided with a gastric injection syringe with a cut and polished needle with a plum-shaped welding on the end. The elixir solution of $0.9 \%$ sodium chloride solution in a volume of $0.5 \mathrm{ml}$ was administered on an empty stomach after a 12 hour fasting of the animal. The mice were accessed for food two hours after the manipulation. Each dose was studied for 10 animals, the control group (10 mice) were administered intragastrically saline solution. The duration of the mouse observation was 14 days. At the first day the animals were kept under con- 
tinuous observation. The following parameters were used to fix the severity of the toxic effect: general somatic state of animals, intensity and nature of motile activity, features of behavior, skeletal muscle tone, presence and nature of seizure, rate and depth of breathing, movement coordination, condition of hair and skin, mucous color, shells, feed and water intake, changes in body weight. Timeframes of intoxication development and death of animals registration was obligatory.

Acute toxicity of the new hygienic product "Apiprol" was investigated by a single application at the rate of 1000 and $5000 \mathrm{mg} / \mathrm{kg}$ animal weight on the skin of 20 mice for 14 days.

Subacute (chronic) toxicity was studied when elixir was applied to the skin of 10 mice at a single daily dose of 500 $\mathrm{mg} / \mathrm{kg}$ for one month, with the determination of skin sensitivity to a long-term action of the agent, behavioral abnormalities. The mice of the control group were rubbed saline into the skin. The study of subacute toxicity was performed on mature white rats of the Wistar line aged (2.5-3) months, weighing (180-230) g with intragastric administration through a probe in the form of a $2 \%$ aqueous solution at a dose of $500 \mathrm{mg} / \mathrm{kg}$ in the volume of 0.5 $\mathrm{ml}$ for 60 days, the control animals were injected saline. All the animals received a standard complete animal facility diet. The condition of the animals was evaluated by their appearance and behavior, as well as by a number of objective indicators (live weight, analysis of cellular blood composition [5], hemoglobin level [5], blood serum biochemical parameters - protein concentration [6], alkaline phosphatase [7], glucose [8].

The analysis of the functional state of the skin of 10 rats after rubbing of the new preparation diluted with water (1:10) into the exposed areas for 30 days was done according to the severity of inflammatory reaction.

A local irritant effect of the elixir on the OM was examined in 14 white rats daily after application for 3-5 min, monitoring the state of OM for 7 days.

The sensitizing effect of the new agent was studied in applications to 14 shaved lateral trunk surfaces.

The study of reparative activity of the new hygienic product "Apiprol" was carried out on an experimental model of the wound process - a rounded aseptic plane wound [9] in rats kept under conditions of the animal facility of the Odessa National Medical University, with access to water and feed and 12-hour illumination. 28 Wistar rats of 2 months of age, weighing $(220 \pm 10) \mathrm{g}$ after anesthesia with ether in advance dehaired skin body, after the surgical area processing by $70 \%$ alcohol, a rounded plane wound of diameter $1 \mathrm{~cm}$ was made by a sterile scalpel. In order to create the equal wound surfaces, a stencil with a hole of $1 \mathrm{~cm}$ in diameter made of a $2 \mathrm{~mm}$ thick organic glass was used. Rats were expelled from the experiment under anesthesia with thiopental $20 \mathrm{mg} / \mathrm{kg}$ by total bleeding from the heart at the $3 \mathrm{rd}$, 7th and 14th day. All experimental rats were divided into 4 groups: group $1-$ a model of a plate wound with an untreated surface, group 2 (the control) the wound treated with sterile $0.9 \%$ sodium chloride, group
3 (the main) - the wound treated with the new elixir, group 4 (the comparative) - the wound surface treated with comparator agent - elixir "Phytopropolis" (trade mark "Medok", Kharkiv, Ukraine).

The assessment of changes at the area of the simulated wound process was determined by macroscopic (examination) and planimetric methods $[10,11]$.

In order to study the plane wound healing, the wound surface reduction rate in time was calculated, on which the planimetric method was based [10]. At the 3rd, 7th and 14th day cellophane was applied to the wound surface, on which the contours of the wound defect were transferred, then using a trammel, the smallest and the largest diameter of the oval was calculated by the formula $S=\pi R r$, where $R-$ the largest radius of the circle, $\mathrm{r}-$ is the smallest radius of the circle. The wound process model applied by the stencil had a standard plane and was calculated by the formula according to the circle square which was $78.5398 \mathrm{~mm}^{2}$. The percentage of wound area healing was calculated and the wound healing rate at the area of the wound defect was evaluated.

The research and care of laboratory animals was carried out in accordance to the scientific and practical recommendations set out in the "European Convention for the Protection of Vertebrate Animals Used for Experimental and Scientific Purposes" [12] and according to the provisions of the General Ethical Principles for Experiments on Animals, approved on II National Congress of Bioethics (Kyiv, 2004) [13].

All the research results were processed statistically by using the program STATISTICA 6.1 for estimation of errors, their integrity [14].

\section{RESULTS}

The formula of the new dental elixir "Apiprol" includes biologically active components of bee products (propolis, comb capping wax), plant origin compounds, which were determined experimentally by composition. It is known that propolis contains a large number of active compounds, including many classes of polyphenolic compounds, flavones, flavonols, phenolic acid, vegetable oils, esters [15]. It has an effect on the normalization of processes in the human body with simultaneous manifestation of antibiotic, anti-inflammatory, anesthetic, antimicrobial, fungicidal, antioxidant, antitumor, immunostimulating, angioprotective effects. Propolis effects on the regeneration of tissues, promotes rapid epithelialization and wound surfaces healing. Comb capping wax is highly immunostimulating and has antibacterial properties. By their properties, the plant components have an antioxidant effect, inhibiting the occurrence of excessive amount of peroxide compounds that violate the OM cells membrane. Besides, the natural constituents exhibit anti-inflammatory, capillaries strengthening, desensitizing effects, taking part in the regulation of lipid, mineral and water metabolism, the processes of periodontal tissues regeneration.

As a result of choosing optimal concentrations of extracts of phytocomponents and bee products, the new dental elix- 
Table I. The results of the study of acute toxicity of a new hygienic product "Apiprol" with intragastric administration in mice (M $\pm m)$

\begin{tabular}{cccc}
\hline \multirow{2}{*}{ Parameters } & \multicolumn{3}{c}{ Concentration of the used agent } \\
\cline { 2 - 4 } & $\mathbf{5 0} \mathbf{~} \mathbf{g} / \mathbf{k g}, \mathbf{n = 1 0}$ & $\mathbf{5 0 0} \mathbf{~} \mathbf{g} / \mathbf{k g}, \mathbf{n}=\mathbf{1 0}$ & $\mathbf{5 0 0 0} \mathbf{~ m} \mathbf{k g}, \mathbf{n = 1 0}$ \\
\hline General somatic condition & Satisfactory & Satisfactory & Satisfactory \\
\hline Motion activity & Moderate & Moderate & Moderate \\
\hline Seizures & Absent & Absent & Absent \\
\hline Color of mucosa & pale pink & pale pink & pale pink \\
\hline Body weighr & $23 \pm 4.0$ & $23 \pm 3.0$ & $22 \pm 2.0$ \\
\hline Death of animals & 0 & 0 & 0 \\
\hline
\end{tabular}

Table II. Effect of long-term intragastric administration of the new elixir"Apiprol" on increase of weight, parameters of blood cell composition of rats ( $M \pm m$ )

\begin{tabular}{|c|c|c|}
\hline \multirow{2}{*}{ Parameters } & \multicolumn{2}{|c|}{ Group of animals } \\
\hline & control $(n=10)$ & experimental $(n=10)$ \\
\hline $\begin{array}{c}\text { Increase of weight, } \mathrm{g} \\
\text { P }\end{array}$ & $134.6 \pm 10.2$ & $\begin{array}{l}141.0 \pm 8.4 \\
>0.05\end{array}$ \\
\hline $\begin{array}{c}\text { Erythrocytes, } \mathrm{T} / \mathrm{l} \\
\mathrm{P}\end{array}$ & $5.10 \pm 0.24$ & $\begin{array}{l}5.88 \pm 0.32 \\
>0.05\end{array}$ \\
\hline $\begin{array}{l}\text { Leukocyts, } g / l \\
\text { P }\end{array}$ & $10.80 \pm 0.54$ & $\begin{array}{c}11.96 \pm 0.70 \\
>0.05\end{array}$ \\
\hline \multicolumn{3}{|l|}{ Leukogram, \% } \\
\hline $\begin{array}{c}\text { Eosinophils, } \\
\text { P }\end{array}$ & $3.50 \pm 0.30$ & $\begin{array}{c}2.34 \pm 0.24 \\
>0.05\end{array}$ \\
\hline $\begin{array}{l}\text { Rod-like } \\
\text { P }\end{array}$ & $4.30 \pm 0.32$ & $\begin{array}{c}2.66 \pm 0.22 \\
>0.05\end{array}$ \\
\hline $\begin{array}{c}\text { Segmental } \\
\mathrm{P}\end{array}$ & $30.20 \pm 0.80$ & $\begin{array}{l}31.00 \pm 1.40 \\
\quad>0.05\end{array}$ \\
\hline $\begin{array}{c}\text { Lymphocytes } \\
\text { P }\end{array}$ & $58.40 \pm 1.60$ & $\begin{array}{l}62.00 \pm 2.00 \\
>0.05\end{array}$ \\
\hline $\begin{array}{c}\text { Monocytes } \\
\text { P }\end{array}$ & $3.00 \pm 0.40$ & $\begin{array}{c}2.00 \pm 0.20 \\
>0.05\end{array}$ \\
\hline
\end{tabular}

Note. $P$ - is the probability index calculated in relation to the control group

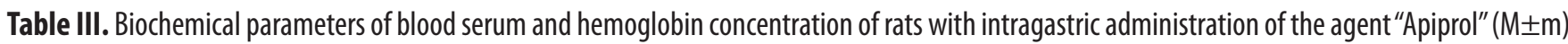

\begin{tabular}{|c|c|c|}
\hline \multirow{2}{*}{ Parameters } & \multicolumn{2}{|c|}{ Groups of animals } \\
\hline & control $(n=10)$ & experimental $(n=10)$ \\
\hline $\begin{array}{l}\text { Blood hemoglobin, } \mathrm{mmol} / \mathrm{l} \\
\mathrm{P}\end{array}$ & $8.82 \pm 0.14$ & $\begin{array}{l}9.38 \pm 0.18 \\
>0.05\end{array}$ \\
\hline $\begin{array}{c}\text { Protein level, } g / l \\
\text { P }\end{array}$ & $1.32 \pm 0.11$ & $\begin{array}{l}1.10 \pm 0.10 \\
>0.05\end{array}$ \\
\hline $\begin{array}{c}\text { Alkaline phosphatase, } \mu \mathrm{kat} / \mathrm{l} \\
\mathrm{P}\end{array}$ & $0.64 \pm 0.04$ & $\begin{array}{l}0.70 \pm 0.05 \\
>0.05\end{array}$ \\
\hline $\begin{array}{c}\text { Glucose, } \mathrm{mmol} / \mathrm{l} \\
\mathrm{P}\end{array}$ & $5.8 \pm 0.2$ & $\begin{array}{l}5.8 \pm 0.2 \\
>0.05\end{array}$ \\
\hline
\end{tabular}

Note. $P$ - is the probability index calculated in relation to the control group.

ir was developed, the prospect of which can be determined first of all by toxicological and hygienic studies.

Oral administration of the new product in different concentrations to mice did not result in death of animals in any case. There were no changes in behavior and in the weight of animals, general somatic condition of the animals was satisfactory, there was a moderate motion activity (Table I).
According to obtained results the investigated agent is not toxic, on this occasion LD 50 is impossible to calculate.

When studying acute toxicity with a single application of the new product at a rate of $5000 \mathrm{mg} / \mathrm{kg}$ of animal weight on the skin in 5 mice did not reveal signs of intoxication and reliable difference from the animals of the control group, which were rubbed saline solution, no animals died during the observation (10 days). 
Table IV. Results of planimetric study

\begin{tabular}{ccc}
\hline Animal groups & Healing of wound area at the $\mathbf{1 4}^{\text {th }}$ day (\%) & Rate of wound healing $\left(\mathbf{M m}^{\mathbf{2}} \mathbf{/ d}\right)$ \\
\hline Model of wound, $\mathrm{n}=8$ & 93.4 & 5.20 \\
\hline Control group, $\mathrm{n}=8$ & 93.8 & 5.25 \\
\hline Main group, $\mathrm{n}=8$ & 97.0 & 5.44 \\
\hline Comparison group, $\mathrm{n}=8$ & 94.6 & 5.30 \\
\hline
\end{tabular}

Table V. Changes of wound damage area in rats under the influence of the hygienic means $(M \pm m, m m 2)$

\begin{tabular}{ccccc}
\hline \multirow{2}{*}{$\begin{array}{c}\text { Groups of animals } \\
\text { Model of wound } \\
n=8\end{array}$} & before treatment & $\mathbf{3}^{\text {rd }}$ day & $\mathbf{7}^{\text {th }}$ day & $\mathbf{1 4}^{\text {th }}$ day \\
\cline { 2 - 4 } & $78.5 \pm 0.1$ & $72.4 \pm 0.2$ & $46.2 \pm 0.2$ & $5.2 \pm 0.1$ \\
\hline $\begin{array}{c}\text { Control } \\
n=8\end{array}$ & $78.5 \pm 0.1$ & $69.6 \pm 0.2$ & $34.4 \pm 0.3$ & $4.9 \pm 0.1$ \\
$P$ & & $<0.05$ & $<0.05$ & $<0.05$ \\
\hline Main & $78.5 \pm 0.1$ & $42.8 \pm 0.3$ & $17.6 \pm 0.2$ & $2.3 \pm 0.1$ \\
$n=8$ & $<0.05$ & $<0.05$ & $<0.05$ \\
$P$ & & $<0.05$ & $<0.05$ & $<0.05$ \\
$P_{1}$ & & $<0.05$ & $<0.05$ & $<0.05$ \\
\hline$P_{2}$ & $78.5 \pm 0.1$ & $57.6 \pm 0.2$ & $28.2 \pm 0.2$ & $4.2 \pm 0.1$ \\
$n=8$ & & $<0.05$ & $<0.05$ & $<0.05$ \\
$P$ & & $<0.05$ & $<0.05$ & $<0.05$ \\
\hline$P_{1}$ & & &
\end{tabular}

Notes: $\mathrm{P}$ - significant difference for the group of the wound model; $\mathrm{P}_{1}$ - significant difference for the control group ; $\mathrm{P}_{2}-$ significant difference for the group of comparison.

When studying acute toxicity, the animals of the research groups who received the new product did nor differ from the animals of the control group by appearance and behavior. The increase in weight of rats was greater than in the corresponding control group.

Analysis of the cellular composition of blood is presented in table II [5]. The data evidence that the cellular composition of the blood of rats, which received the new elixir, did nor signficanly differ from the corresponding parameters of control.

Table III presents the results of biochemical studies of blood serum and blood hemoglobin concentration of rats that received the new hygienic product intragastrically.

All the tested biochemical parameters of blood serum were not significantly different from the control, indicating that there were no metabolic disorders.

The presented results of biochemical studies indicate safety of the new hygienic agent, as evidenced by the lack of significant differences in the parameters of the experimental and control groups.

Study of subacute toxicity when applied to the skin of 10 rats at a single daily dose of $500 \mathrm{mg} / \mathrm{kg}$ of elixir during the month did not reveal any abnormalities in the behavior or physiological condition as compared with the control animals.

According to the results of toxicological studies and microscopic examination of the internal organs at autopsy of animals after euthanasia on the $3 \mathrm{rd}, 7 \mathrm{th}, 14 \mathrm{th}, 30 \mathrm{th}, 40 \mathrm{th}$, 60th day of the experiment did not reveal any deviations from the norm.

The histomorphological picture of the vital parenchymatous organs of rats: liver, kidney, spleen, heart, lungs, stomach did not reveal the presence of toxic effect of the new hygienic agent on organ tissues with repeated administration, which is safe.

At present, no data on absorption in the gastrointestinal tract of constituents of the new elixir have been identified in the scientific literature, which eliminates their resorptive action and confirms non-toxicity.

Analysis of the functional state of the skin by severity of inflammatory reaction in 10 white rats after rubbing-in of the diluted elixir (1:10) into the exposed area for 30 days determined that the index of skin irritation was 0 points, so irritation was absent.

Local irritation of the new agent on OM was examined in 14 white rats daily after application for 2-3 min, monitoring the state of OM for 7 days. The irritation ratio was determined to be less than 0.1 , indicating no irritation.

The results determine sensitizing action of the elixir with application to the shaved lateral areas of the trunk showed no sensitization when the index is less than $1(S=0.36 \pm 0.04)$.

Positive dynamics of wound healing process was revealed macroscopically (visually) in animals that received topical application of hygiene products based on propolis, which was confirmed by a quantitative calculation by the planimetry method (Table IV). 
The difference at the area of wound defect of the animals, which were made application with the new product, and in rats of the control and comparative groups was determined on the 3 rd day of the experiment. On the 7 th day, it was determined that the wound area in the group of rats treated with the new elixir was significantly reduced as compared to the control and comparison groups. On the 14th day, the reduction of the wound area in the animals after the application of the new hygiene product was significantly more pronounced as compared to other experimental animals and almost complete healing was observed. The difference in changes at the wound area in rats of the main and comparative group was on the 3 rd day $-25.7 \%$, on the 7 th day $-37.5 \%$ and on the 14 th day $-45.2 \%$ (Table V).

\section{DISCUSSION}

The dynamic nature of the wound healing process in animals against the background of the newly created hygienic means reflects the pronounced activity of proliferative processes in the wound. According to the obtained data, we can assume that the significant level of phenolic compounds in the tooth elixir causes the activation of cell mitosis with stimulation of regeneration, inhibition of the inflammatory response, antibacterial effect. It is obvious that these mechanisms are associated with accelerated healing when using the new elixir.

It is known that phenolic compounds, as well as vitamins, biologically active substances of plant adaptogens, which include flavonoids, carotenoids, tocopherols, perform a protective function, an important element of which is the antioxidant effect $[16,17]$. Inhibiting the intensity of free radical oxidation of biomacromolecules in wound processes and stabilizing tissue antioxidants as well, they help restoring tissue function and structure. Besides, the compounds have anti-inflammatory, capillary-strengthening effects, participate in the regulation of lipid, mineral, water metabolism, periodontal tissue regeneration processes. In combination with ascorbic acid, flavonoids are involved in oxidation-reduction processes that promote healing. The results are in accord with the data of the authors [18-20], who showed increased tissue regeneration when using flavonoid-containing agents by activating antioxidant protection and increasing the level of nucleic acids, which provides a high rate of the course of all phases of the wound process.

\section{CONCLUSIONS}

1. A complete safety of the new hygienic product "Apiprol" for the oral cavity - a tooth elixir on the basis of biologically active substances of bee products and compounds of plant origin - during studies of acute and subacute toxicity was determined.

2. Reparative activity of the new product "Apiprol" for oral cavity was determined on the model of wound process (a rounded aseptic planar skin-fascial wound), which is better in drug of comparison "Phytopropolis."
3. The research results indicate the prospect of further study of the new elixir properties in order to create a greater variety of home produced dental means for dental institutions practice.

\section{REFERENCES}

1. Denga O.V., Pindus T.A, Verbitskaya T.G. Molekulyarno-geneticheskaya otsenka markerov zhirovogo obmena i vospaleniya u patsientov $s$ parodontitom na fone metabolicheskogo sindroma [Molecular-genetic evaluation of markers of fat metabolism and inflammation in patients with periodontitis on the background of metabolic syndrome]. Vestnik morskoy meditsiny. 2017;4:149-154. (In Russian)

2. Pindus T.A. Sostoyanie funktsionalnykh reaktsiy v tkanyakh parodonta pri khronicheskom generalizovannom parodontite i metabolicheskom sindrome v protsesse lechebno-profilakticheskikh meropriyatiy [Functional reactions in periodontal tissues in chronic generalized periodontitis and metabolic syndrome in the course of therapeutic and prophylactic measures]. Scientific pages. 2018;8:10-13. (In Russian)

3. Kravchenko L.S., Appelkhans 0.L., Ivanova Ya.I., Goncharenko O.V. Zayavka na vynakhid Ukrainy a202002339 vid 10.04.2020. Zubnyi eliksir dlya mistsevoyi profilaktyky i likuvannya zapalnykh protsesiv slyzovoyi obolonky porozhnyny rota ta tkanyn parodonta [Dental elixir for local prevention and treatment of inflammatory processes of the oral mucosa and periodontal tissues]. (in Ukrainian)

4. Metodicheskieukazaniya po eksperimentalnomu(farmakologicheskomu) iklinicheskomu ispytaniyu gigienicheskikh ilechebno-profilakticheskikh sredstv dlya ukhoda za polostyu rta. Farmkomitet MZ Ukrainy [Methodological instructions for experimental (pharmacological) and clinical testing of hygienic and therapeutic prophylactic agents in oral care]. 1994, 43 p. (in Russian)

5. Goryachkovskiy A.M. Klinicheskaya biokhimiya v laboratornoy diagnostike [Clinical biochemistry in laboratory diagnostics] 3rd. ed, Odessa; Ekologiya, 2005, 616 p. (in Russian)

6. Lowry 0.H., Rosebrough N.J., Farr A.L., Randall R.I. Protein measurement with Folin phenol reagent. J. Biol. Chem, 1951;193:265-275.

7. Levitskiy A.P., Marchenko A.I., Rybak T.L. Sravnitelnaya kharakteristika trekh metodov opredeleniya fosfataz slyuny cheloveka [Comparative characterization of three methods for the determination of phosphatase of human saliva]. Laboratornoe delo, 1973;10:624-625. (in Russian)

8. DeFina L.F. Vega G.L. Leonard D. Grundy S.M. Fasting glucose, obesity and metabolic syndrome as predictors of type 2 diabetes: Cooper Center Longitudinal Stady. J. Investig. Med. 2012;60, 8: 1164-1168.

9. Kuzina M.I., Kostyuchenok B.M. Ranyiranevaya infektsiya [Wounds and wound infection]. A manual for doctors. Moscow, Meditsina, 1990,591 p. (in Russian)

10. PopovV.A. Ranevoyprotsess: nanobiotehnologiioptimizatsii [Thewound process: nanobiotechnology optimization].SPb, Spets. Lit. 2013, 199 p. (in Russian)

11. Khabraev R.Ts. Rukovodstvo po eksperimentalnomu (doklinicheskomu) izucheniyu novykh farmakologicheskikh veschestv [A guide for experimental (preclinical) study of new pharmacological substances]. 2nd revised edition, Moscow, OAO Meditsina, 2012, 832 p. (in Russian)

12. Kozhemyakin Yu.M., Khromov O.S., Filonenko M.A., Saifetdinova G.A. Naukovo-praktychni rekomendatsii z utrymannya laboratornykh tvaryn ta roboti z nymy [Scientific and practical recommendations for keeping and working with laboratory animals], Kyiv Avitsenna, 2002, 156p. (in Ukrainian)

13. Kosenko K.M.,Sukmanskiy 0.I. Eksperymentalne modelyuvannya khvorob, za ta proty: bioetychni aspekty [Experimental modeling of diseases pros and cons: bioethical aspects]. Materialy Natsionalnogo kongresu z bioetyky zmizhnarodnoyu uchastyu, Kyiv, 2004, p. 163-164. (in Ukrainian) 
14. Glants S. Mediko-biologicheskaya statistika [Biomedical statistics]. Moscow, Praktika, 1998, 459 p. (in Russian)

15. De Groot A.C. Propolis: a review of properties, applications, chemical composition, contact allergy and other adverse effects. Dermatitis, 2013;24(6):263-282.

16. Kurkin V.A., Kurkina A.V., Avdeeva E.V. Flavonoidyi kak biologicheski aktivnyie soedineniya lekarstvennykh rasteniy [Flavonoids as biologically active compounds of medicinal plants]. Fundamentalnyie issledovaniya. 2013;11:1897-1901. (in Russian)

17. Makarov V.G., Makarova N.M., Selezneva A.I. Izuchenie mehanizma antioksidantnogo deystviya vitaminov i flavonoidov [Study of the mechanism of antioxidant action of vitamins and flavonoids]. Voprosy pitaniya. 2005;74(1):10-13. (in Russian)

18. Kolsanov A.V., Tolstov A.V., Voronin A.S. Novoe v lechenii ran i ranevykh protsessov kozhi i myagkikh tkaney [Novelty in the treatment of wounds and wound processes of the skin and soft tissues. Vestnik novykh meditsinskikh tekhnologiy].2011;3:146. (in Russian)

19. Belonogova V.D., Korepanova N.S., Oleshko G.I. et al. Nekotoryie aspekty izucheniya biologicheski aktivnykh veshchestv i farmakologicheskikh svoystv lekarstvennykh rasteniy [Some aspects of studying biologically active substances and pharmacological properties of medicinal plants]. Voprosyi biol. med. i farmatsevt. khimii. 2008;4:16-20. (in Russian)

20. Grabarskaya E.A., Danilevskaya N.V., Deltsov A.A., Pravda A.A. Izuchenie ranozazhivlyayushchey aktivnosti novoy mnogokomponentnoy mazi [Study of the wound healing activity of a new multicomponent ointment]. RVZh MDZh. 2015;3:48-50. (in Russian)

\section{ORCID and contributionship:}

Lyudmila Kravchenko: 0000-0002-9228-3313 ${ }^{A, F}$

Elena Appelkhans: 0000-0003-4001-5242 B,D,F

Liana Unhurian: 0000-0001-5391-9676 ${ }^{A, C, F}$

Sergey Shcherbakov: 0000-0003-3822-765X $X^{A, E}$

Olga Goncharenko: 0000-0001-6534-8778 B,D,F

Yana Ivanova: 0000-0001-7796-8034 $4^{A, D}$

\section{Conflict of interest:}

The Authors declare no conflict of interest.

\section{CORRESPONDING AUTHOR}

\section{Liana Unhurian}

Odesa National Medical University,

2 Valikhovsky Lane, 65000 Odesa, Ukraine

tel: +380979069009

e-mail: lianau@ukr.net

Received: 10.06 .2020

Accepted: 02.06 .2021

A - Work concept and design, B - Data collection and analysis, C - Responsibility for statistical analysis, D-Writing the article, $\mathbf{E}$-Critical review, $\mathbf{F}$ - Final approval of the article 